Article

\title{
Beneficial Health Potential of Algerian Polysaccharides Extracted from Plantago ciliata Desf. (Septentrional Sahara) Leaves and Seeds
}

\author{
Noura Addoun ${ }^{1}$, Zakaria Boual ${ }^{1,2}$, Cédric Delattre ${ }^{3,4}{ }^{D}$, Toufik Chouana ${ }^{1}{ }^{(D}$, Christine Gardarin $^{3}$, \\ Pascal Dubessay ${ }^{3}$, Fatima Benaoun ${ }^{1}$, Seddik Addaoud ${ }^{1}$, Mohamed Didi Ould El Hadj ${ }^{1}$, Philippe Michaud ${ }^{3} \mathbb{D}$ \\ and Guillaume Pierre ${ }^{3, *}$ (D)
}

Citation: Addoun, N.; Boual, Z.; Delattre, C.; Chouana, T.; Gardarin, C.; Dubessay, P.; Benaoun, F.; Addaoud, S.; Ould El Hadj, M.D.; Michaud, P.; et al. Beneficial Health Potential of Algerian Polysaccharides Extracted from Plantago ciliata Desf. (Septentrional Sahara) Leaves and Seeds. Appl. Sci. 2021, 11, 4299. https://doi.org/10.3390/ app11094299

Academic Editor: Ana M. L. Seca

Received: 12 April 2021

Accepted: 30 April 2021

Published: 10 May 2021

Publisher's Note: MDPI stays neutral with regard to jurisdictional claims in published maps and institutional affiliations.

Copyright: (c) 2021 by the authors. Licensee MDPI, Basel, Switzerland. This article is an open access article distributed under the terms and conditions of the Creative Commons Attribution (CC BY) license (https:/ / creativecommons.org/licenses/by/ $4.0 /)$.
1 Laboratoire de Protection des Ecosystèmes en Zones Arides et Semi-Arides, Université Kasdi Merbah, Ouargla 30000, Algeria; nourabio14@gmail.com (N.A.); biozakaria1983@gmail.com (Z.B.); chouanatoufik@yahoo.fr (T.C.); biodoctorante@gmail.com (F.B.); adseddik@gmail.com (S.A.); mohameddidi@yahoo.fr (M.D.O.E.H.)

2 Laboratoire de Biologie Médicales IBN ROCHD, Rue Khemisti, 47000 Ghardaïa, Algeria

3 Université Clermont Auvergne, CNRS, SIGMA Clermont, Institut Pascal, 63000 Clermont-Ferrand, France; cedric.delattre@uca.fr (C.D.); christine.gardarin@uca.fr (C.G.); pascal.dubessay@uca.fr (P.D.); philippe.michaud@uca.fr (P.M.)

4 Institut Universitaire de France (IUF), 1 rue Descartes, 75005 Paris, France

* Correspondence: guillaume.pierre@uca.fr; Tel.: +33-(0)-473-407-222

Featured Application: This study substantially contributes to raising the understanding, safety, and efficiency of ethnobotanical remedies from Plantago ciliata employed by traditional healers in various Algerian health disorders.

Abstract: Today, an ethnobotanical approach makes sense for identifying new active bioactive chemicals from uses of indigenous plants. Two water-soluble enriched polysaccharide fractions (L-PSPN and S-PSPN) were extracted by hot water extraction from the leaves and seeds of Plantago ciliata Desf. (1798), a Mzab indigenous herb currently used in Algeria by traditional healers. Primary investigation was performed for describing the main structural features of these polysaccharides (pectinand heteroxylan-like compositions) by using colorimetric assays, FTIR spectroscopy, HPAEC/PAD and GC/MS-EI analyses. Some biological activities were also monitored, such as anticomplement, anti-inflammatory (phagocytic ability, NOX2 and MPO inhibitions) and anti-diabetic ( $\alpha$-amylase and $\alpha$-glucosidase inhibitions). L-PSPC seems able to moderately modulate innate immune system ( $\mathrm{IC}_{50}$ around $100 \mu \mathrm{g} / \mathrm{mL}$ ) and contribute to wound-healing processes ( $\mathrm{IC}_{50}$ close to $217 \mathrm{vs}$. $443 \mu \mathrm{g} / \mathrm{mL}$ for sodium heparin). S-PSPC shows some potential as an anti-hyperglycemic $\left(\mathrm{IC}_{50}\right.$ around $4.7 \mathrm{mg} / \mathrm{mL}$ ) and anti-inflammatory ( $\mathrm{IC}_{50}$ ranging from 111 to $203 \mu \mathrm{g} / \mathrm{mL}$ ) agent, as well as other (fiber) psyllium-like polysaccharides extracted from Plantago species.

Keywords: Plantago ciliata; polysaccharides; characterization; biological activities; Africa

\section{Introduction}

Herbal medicines have attracted considerable interest as alternative anti-inflammatory remedies due to their large therapeutic properties, low toxicity and costs [1]. Today, involved mechanisms of anti-inflammatory remain unclear [2] and potentiating innate immune system has been recognized as a possible way for inhibiting inflammation growth without harming the host [3].

Polysaccharides from various traditional medicinal herbs have been shown to be immunopotentiating, in vitro as well as in vivo [4]. Many reports on the biological activities of polysaccharides from Plantago highlighted that species belonging to this genus showed anti-inflammatory effects and immune enhancements through specific and non-specific 
immunity, anti-peroxidation of lipids, antidiabetic, and reduction in serum lipids [5]. Arabinogalactan Type II were isolated from the leaves of Plantago major and shown anticomplementary activity [6]. A highly branched heteroxylan from Plantago asiatica seeds could induce maturation of murine dendrite cells, promote defecation and have antioxidant activity [7]. Intake of a Plantago ovata husk-supplemented diet prevented endothelial dysfunction, obesity development, and improved dyslipidemia, abnormal plasma concentrations of adiponectin and TNF- $\alpha$ (tumor necrosis factor- $\alpha$ ) in obese Zucker rats [8]. The polysaccharides from Plantago palmata leaves possessed immunomodulatory properties by stimulating NO (nitric oxide) and TNF- $\alpha$ production by activated macrophages [9]. A rhamnoarabinogalactan extracted from aerial parts of Plantago lanceolata was able to inhibit the peroxidation of soybean lecithin liposomes with $\mathrm{OH}$ (hydroxyl) radicals. This polysaccharide showed a high antioxidant activity of $19.1 \%$ at $0.23 \mathrm{mM}$, which represented $45.3 \%$ of the activity of $\alpha$-tocopherol standard [10].

Today, identifying, characterizing, and evaluating the potential health benefits of new polysaccharides from African medicinal plants have become a challenge. Plantago ciliata, belonging to Plantaginaceae, is a traditional Algerian herbal plant abundantly distributed in the northeast region of Sahara. It has been reported for having many supposed ethnopharmacological properties including anti-inflammatory, anti-ulcer, anticough, and anti-diabetic activities [11]. To our knowledge, no studies deal with the chemical elucidation and some biological benefits of two water-soluble polysaccharides extracted from Plantago ciliata leaves (L-PSPC) and seeds (S-PSPC).

Preliminary structural features of both fractions were determined by colorimetric assays, Fourier Transform Infrared (FTIR) spectroscopy, High-Pressure Anion Exchange Chromatography equipped with Pulsed Amperometric Detection (HPAEC/PAD) and Gas Chromatography coupled to Mass Spectrometry with Electronic Impact (GC/MS-EI) analyses. Some biological activities were monitored (anticomplement, anti-inflammatory, anti-diabetic) regarding the structures of polysaccharides (structure/function relationship) and current literature.

\section{Materials and Methods}

\subsection{Raw Material and Chemicals}

Plantago ciliata Desf. (1798) (Fl. Atlant), abbreviated P. ciliata (Conservatoire et Jardin botaniques de Genève \& South African National Biodiversity Institute, number collection cc3472, record n`115142 modified 10 April 2008; taxonomic number 1737; nomenclatural Tela Botanica number: 115142), was freely (not protected) harvested and taxonomically identified by Z. Boual and A. Chehma from ECOSYS laboratory (Université Kasdi Merbah, Ouargla) entitled by Algerian Government for botanical exploration and use of Saharan plants in Algeria. P. ciliata leaves and seeds were collected from Oued nechou (region of Ghardaïa), in March-April 2015 and April 2017, respectively. The ears of each plant were cut out and dried at room temperature for three weeks in the dark. The leaves were cut into smaller parts then air-dried at ambient temperature in an environment with no direct sunlight and stored in kraft paper bags (room temperature). The seeds were manually isolated from the dry ears and also stored in kraft paper bags (room temperature).

Zymosan-A (Saccharomyces cerevisiae origin) were purchased from Fluka (Bio Chemika). Coomassie Brilliant Blue G-250 was purchased from Serva (Canada). Heparin H 108 (sodium salt, from hog intestin mucosa, specific anticoagulant activity $173 \mathrm{IU} / \mathrm{mg}$ ) was obtained from SANOFI (Suresnes, France). Clofenal@(diclofenac) was from Saidal group. The human peripheral blood was obtained from healthy donors ranging from 20 to 35 years old. Whole blood was collected in a vacutainer consisting of $\mathrm{NH}$ sodium Heparin as anti-coagulant. All other chemicals and buffers were purchased from Sigma-Aldrich and were of analytical grade. 


\subsection{Polysaccharides Extractions}

Two different polysaccharidic fractions were extracted from Plantago ciliata leaves (L-PSPC) and seeds (S-PSPC). First, Plantago ciliata leaves (100 g) were grounded (150200 mesh) and exhaustively extracted with $60 \mathrm{~mL}$ n-hexane $96 \%$ and $60 \mathrm{~mL}$ methanol 99\% using a solvent extractor (SER 148, Velp Scientifica) to remove hydrophobic and low molecular weight compounds (LMW). After filtration through a gauze (100 mesh), the residues were dried at room temperature, and then extracted three times with deionized water (1:20 w:v) under constant stirring $(150 \mathrm{rpm})$ for $2 \mathrm{~h}$ at $60^{\circ} \mathrm{C}$. The preparation was then centrifuged at $10,000 \mathrm{~g}$ and $25^{\circ} \mathrm{C}$ for $10 \mathrm{~min}$ to remove remaining leaves and obtain a mucilage enriched fraction. This solution was concentrated to one fourth of the original volume by vacuum evaporation. Aqueous solution of 5\% TCA (trichloroacetic acid) was used to precipitate the proteins. The mucilage enriched fraction was then dialyzed in membrane dialysis tubes with a cut-off of 12-14 kDa (Spectra/pore, Spectrum Labs, USA) for $72 \mathrm{~h}$ against distilled water at $4{ }^{\circ} \mathrm{C}$ to remove salts and other LMW compounds. The polysaccharides were precipitated by the addition of absolute ethanol to a final concentration of $75 \%(v / v)$, and recovered by centrifugation at $4000 \mathrm{~g}$ and $25^{\circ} \mathrm{C}$ for $20 \mathrm{~min}$. Finally, the crude water-soluble polysaccharides fraction (L-PSPC) was washed with $10 \mathrm{~mL}$ acetone $100 \%$, dissolved in $5 \mathrm{~mL}$ of deionized water and freeze-dried.

Secondly, Plantago ciliata seeds $(211 \mathrm{~g})$ were macerated for $4 \mathrm{~h}$ at $60^{\circ} \mathrm{C}$ under stirring (450 rpm) in ultra-pure water $(5 \% w / v)$. The residues were sequentially filtered (100 mesh at the end), solubilized at $50 \mathrm{~g} / \mathrm{L}$ in ultra-pure water $\left(60^{\circ} \mathrm{C}\right)$ then precipitated by adding three volumes of cold ethanol $\left(96 \%,-20^{\circ} \mathrm{C}\right)$ under stirring. The pellet was recovered after centrifugation at $10,000 \mathrm{~g}$ and $4{ }^{\circ} \mathrm{C}$ for $15 \mathrm{~min}$. The same loop of alcoholic precipitation was performed three times. The final pellet was washed two times against pure acetone on a frit glass $(16-40 \mu \mathrm{m})$ under vacuum. The final enriched fraction (S-PSPC) was crushed into a fine powder $(<3 \mathrm{~mm})$.

\subsection{Determining Biochemical Compositions}

Total carbohydrate and neutral sugar contents were determined by phenol-sulfuric acid [12] and 1,3-dihydroxybenzen [13] methods, respectively, using Glc (Glucose) as standard. Uronic acids were quantified using $m$-hydroxydiphenyl assay using GlcA (Glucuronic acid) as standard [14]. Protein content was estimated by Coomassie Brilliant Blue G-250 method using bovine serum albumin as standard [15]. Phenolic compounds (gallic acid equivalents) were determined according to Folin-Ciocalteu assay [16].

\subsection{FTIR Footprints}

Fourier Transform Infrared (FTIR) spectroscopy experiments were performed on a VERTEX 70 FTIR apparatus equipped with an ATR A225 diamante. Fifty scans were measured at laboratory temperature ranging from 4000 to $400 \mathrm{~cm}^{-1}$. Reference (20 background scans) was made against air. OPUS 7.2 software (Bruker) was used for treating data.

\subsection{Monosaccharide Compositions by HPAEC-PAD en GC/MS-EI}

Monosaccharide compositions of both L-PSPC and S-PSPC were conducted by Gas Chromatography coupled to Mass Spectrometry with Electronic Impact (GC/MS-EI) and High-Pressure Anion Exchange Chromatography equipped with Pulsed Amperometric Detection (HPAEC-PAD) to ensure data complementarity. The results were expressed in molar ratio. All the experiments were done in triplicate.

\subsubsection{GC/MS-EI Experiments}

The analyses of monosaccharides compositions by GC/MS-EI were conducted according to the method of Pierre et al. [17]. Ten mg of polysaccharides were hydrolyzed with 2M TFA (trifluoroacetic acid) for $90 \mathrm{~min}$ at $120^{\circ} \mathrm{C}$ under stirring. The hydrolysates were trimethylsilylated using BSTFA: TMCS (N,O-bis[trimethylsilyltrifluoroacetamide] w: $1 \%$ trimethylchlorosilane) (99:1), evaporated under dry nitrogen then finally solubilized into 
dichloromethane. This procedure was applied for standards including Ara (Arabinose), Glc, Gal (Galactose), GalA (Galacturonic acid), Rha (Rhamnose), Xyl (Xylose). GC/MSEI system was an Agilent 6890 GC / 5973 Network Mass Selective Detector, equipped with an OPTIMA-1MS Accent column (Macherey-Nagel; $30 \mathrm{~m}, 0.32 \mathrm{~mm}, 0.25 \mu \mathrm{m}$ ), using the following parameters, for instance, target ion: $40-800 \mathrm{~m} / \mathrm{z}$, injector line temperature: $250{ }^{\circ} \mathrm{C}$, trap temperature: $150{ }^{\circ} \mathrm{C}$, split ratio: $50: 1$, helium pressure: 8.8 psi; helium flow rate: $2.3 \mathrm{~mL} / \mathrm{min}$, ionization: $70 \mathrm{eV}$, rise in temperature: starting at $100{ }^{\circ} \mathrm{C}$ during $3 \mathrm{~min}$, $8{ }^{\circ} \mathrm{C} / \mathrm{min}$ up to $200^{\circ} \mathrm{C}$ for $1 \mathrm{~min}$ and then $5{ }^{\circ} \mathrm{C} / \mathrm{min}$ up to $215^{\circ} \mathrm{C}$. Data were analyzed with MestReNova 7.1. software (Mestrelab Research, USA).

\subsubsection{HPAEC-PAD Experiments}

Both fractions were hydrolyzed using the same procedure described for GC/MS-EI (see Section 2.5.1). $\mathrm{pH}$ was neutralized after hydrolysis with ammonium hydroxide ( $35 \%$ $w / v)$ then filtered $(0.22 \mu \mathrm{m})$. Samples were injected on a precolumn CarboPac PA1-column $(4 \times 50 \mathrm{~mm})$ and an analytical CarboPac PA1-column $(4 \times 250 \mathrm{~mm})$ equilibrated $15 \mathrm{~min}$ with $18 \mathrm{mM} \mathrm{NaOH}$, using an ICS 3000 System (Dionex Corporation, Sunnyvale (CA), USA) equipped with PAD and AS 50 autosampler. Samples were eluted isocratically at $1 \mathrm{~mL} / \mathrm{min}$ and $25{ }^{\circ} \mathrm{C}$ with the following conditions: $18 \mathrm{mM} \mathrm{NaOH}$ for $25 \mathrm{~min}$, then a linear gradient between 0 to $0.5 \mathrm{M}$ sodium acetate in $200 \mathrm{mM} \mathrm{NaOH}$ for $20 \mathrm{~min}$ to elute acidic monosaccharides. Each run was followed by 15 min washing with $200 \mathrm{mM} \mathrm{NaOH}$. Same set of monosaccharides were used as standards for quantification with a Dionex Chromeleon 6.80 software (Sunnywale, CA, USA).

\subsection{Biological Activities}

Regarding the structural features obtained for L-PSPC and S-PSPC, some biological activities were monitored (anticomplement, anti-inflammatory, anti-diabetic) according to the famous structure/function relationship and data described in the literature.

\subsubsection{Phagocytotic Activity}

Phagocytic ability of polymorphonuclear leukocytes (PMNs) from human peripheral blood was measured using Candida albicans yeast. Briefly, C. albicans (ATCC 2091) was inoculated into Sabouraud liquid broth from a stock culture maintained on a Sabouraud agar slope and left overnight at $30^{\circ} \mathrm{C}$. The culture was washed three times with phosphatebuffered saline (PBS) and incubated for $1 \mathrm{~h}$ at $90^{\circ} \mathrm{C}$ to inactive the yeasts. Cell concentrations in PBS is estimated by measuring absorbance at $540 \mathrm{~nm}$. The absorbance is adjusted to 1.0 which approximately corresponds to $1 \times 10^{7}$ blastoconidia of C. albicans / $\mathrm{mL}[18,19]$. Forty $\mu \mathrm{L}$ of polysaccharides (L-PSPC) were mixed with $200 \mu \mathrm{L}$ heparinized blood and incubated in closed shaking water bath at $37^{\circ} \mathrm{C}$ for $60 \mathrm{~min}$ (60 rpm). After that, tubes were put on ice to stop the reaction. Mixed samples were added with $40 \mu \mathrm{L}$ of $C$. albicans at $0{ }^{\circ} \mathrm{C}$. Samples were incubated in shaking water bath for $10 \mathrm{~min}$ at $37^{\circ} \mathrm{C}$, while for negative control; the samples were put on ice. After incubation, the samples were put on ice to stop the reaction. Next, samples were washed twice with $3 \mathrm{~mL}$ of PBS. Then, samples were added $2 \mathrm{~mL}$ of lysing solution to lyse erythrocytes and incubated at room temperature for $20 \mathrm{~min}$. Zymosan was used as a positive control. After lysing, PMNs were washed with PBS by centrifugation for $5 \mathrm{~min}$ at $1000 \mathrm{~g}$ three times and then fixed in ethanol. The fixed specimens were mounted on the glass slide and stained with May-Grünwald-Giemsa. The cells with and without phagocytized yeasts out of a total of at least 100 cells were counted by direct visual enumeration using a light microscope $(1000 \times)$.

\subsubsection{Anti-inflammatory Activity}

Immunomodulating potential of S-PCPC was evaluated by determining the capacity to inhibit the enzymatic activities of NADPH oxidase (NOX2) and myeloperoxidase (MPO). MPO activity was measured using adapted methods from Wanikiat et al. and Meziti et al. $[20,21]$. Briefly, $175 \mu \mathrm{L}$ of cell suspension $\left(6 \times 10^{6}\right.$ cells $\left./ \mathrm{mL}\right)$ were pre-incubated 
with $30 \mu \mathrm{L}$ of S-PSPC at different concentrations (5-100 $\mu \mathrm{g} / \mathrm{mL}), 30 \mu \mathrm{L}$ of different dilutions $(5-100 \mu \mathrm{g} / \mathrm{mL}$ ) of diclofenac (positive control) or $30 \mu \mathrm{L}$ of PBS (phosphate buffer saline, negative control) for $10 \mathrm{~min}$ at $37^{\circ} \mathrm{C}$, then stimulated with $25 \mu \mathrm{L}$ of PMA (phorbol 12 -myristate 13 -acetate) $\left(10^{-6} \mathrm{M}\right)$ for $10 \mathrm{~min}$ at $37^{\circ} \mathrm{C}$. After centrifugation $(320 \mathrm{~g}$, $10 \mathrm{~min}, 4^{\circ} \mathrm{C}$ ), supernatants were incubated with the reaction mixture: $25 \mu \mathrm{L}$ of 4 -AA (4-aminoantipyrine) $(1 \mathrm{mg} / \mathrm{mL})$ solution in $0.1 \mathrm{M}$ PBS ( $\mathrm{pH}$ 6.0) supplemented with $100 \mu \mathrm{L}$ of $0.003 \% \mathrm{H}_{2} \mathrm{O}_{2}$. The reaction was ended after $5 \mathrm{~min}$ by adding $50 \mu \mathrm{L}$ of $4 \mathrm{M} \mathrm{H}_{2} \mathrm{SO}_{4}$. The absorbances were measured at $\lambda=546 \mathrm{~nm}$. NADPH oxidase activity was measured using the method of Boudoukha which was slightly modified [22]. Briefly, $400 \mu \mathrm{L}$ of cell suspension $\left(6 \times 10^{6}\right.$ cells $\left./ \mathrm{mL}\right)$ was incubated with $100 \mu \mathrm{L}$ of PSPC $(5-100 \mu \mathrm{g} / \mathrm{mL}), 100 \mu \mathrm{L}$ of different dilutions (5-100 $\mu \mathrm{g} / \mathrm{mL}$ ) indomethacin (positive control) or $100 \mu \mathrm{L}$ of PBS (negative control) for $10 \mathrm{~min}$ at $37^{\circ} \mathrm{C}$. The cells were thus stimulated with $100 \mu \mathrm{L}$ of PMA solution $\left(10^{-6} \mathrm{M}\right)$, then incubated for $10 \mathrm{~min}$ at $37^{\circ} \mathrm{C}$. For each tube, $100 \mu \mathrm{L}$ of a freshly prepared Cytochrome $\mathrm{C}$ solution $(0.2 \mathrm{mg} / \mathrm{mL})$ were added followed by incubation for $15 \mathrm{~min}$ at $37^{\circ} \mathrm{C}$. The absorbance of the supernatants obtained after centrifugation ( $400 \mathrm{~g}$, $5 \mathrm{~min}, 4^{\circ} \mathrm{C}$ ) were measured at $\lambda=550 \mathrm{~nm}$. Inhibition activity results were expressed regarding Equation 1 [20]. All the experiments were done in triplicate.

$$
\text { Inhibition } \left.(\%)=\left(1-\left(\mathrm{A}_{(\text {sample })}\right) / \mathrm{A}_{(\text {control })}\right)\right) \times 100
$$

\subsubsection{Anti-complement Activity}

Anti-complement activity was monitored for L-PSPC. Based on a modified method from Mayer, normal human serum (NHS) obtained from healthy male donors (mean age 20 years) was used as the complement source, and it was treated with sheep erythrocyte to remove the anti-sheep erythrocyte antibody. Sheep erythrocytes were washed twice with $150 \mathrm{mM} \mathrm{NaCl}$ and once with gelatin veronal buffer ( $\mathrm{pH} 7.4$, containing $0.1 \%$ gelatin, $141 \mu \mathrm{M} \mathrm{NaCl}, 500 \mu \mathrm{M} \mathrm{MgCl}_{2}, 150 \mu \mathrm{M} \mathrm{CaCl}_{2}$, and $1.8 \mathrm{mM}$ Sodium barbital $\left.\left(\mathrm{GVB}^{2+}\right)\right)$. The NHS was diluted to a concentration giving $50 \%$ hemolysis with $\mathrm{GVB}^{2+}$ in the absence of complement inhibitors. Sensitized erythrocytes were prepared by incubation of sheep erythrocytes $\left(4.0 \times 10^{8}\right.$ cells $\left./ \mathrm{mL}\right)$ with an equal volume of rabbit anti-sheep erythrocyte antibody in GVB2+. Heparin served as the positive control. Each sample was dissolved in $\mathrm{GVB}^{2+}$. Various dilutions of test samples $(100 \mu \mathrm{L})$ were pre-incubated with $100 \mu \mathrm{L}$ of NHS (1:10) and $200 \mu \mathrm{L}$ of $\mathrm{GVB}^{2+}$ at $37^{\circ} \mathrm{C}$ for $10 \mathrm{~min}$. Then, $200 \mu \mathrm{L}$ of sensitized erythrocytes were added, and the mixture was incubated at $37^{\circ} \mathrm{C}$ for $30 \mathrm{~min}$. The reaction mixture was immediately centrifuged at $900 \mathrm{~g}$ for $5 \mathrm{~min}$. Absorbance of the supernatant was measured at $405 \mathrm{~nm}$. Total lysis (100\%) was obtained by adding $400 \mu \mathrm{L}$ of distilled $\mathrm{H}_{2} \mathrm{O}$ to $200 \mu \mathrm{L}$ of sensitized sheep erythrocytes. Samples containing $\mathrm{GVB}^{2+}$, serum, and sensitized sheep erythrocytes were used as background controls (A control). The degree of lysis and inhibition of hemolysis induced by the test samples were calculated according to Equations (2) and (3), respectively. All the experiments were done in triplicate.

$$
\begin{gathered}
\text { Lysis degree }(\%)=\left(\mathrm{A}_{(\text {control })} / \mathrm{A}_{(\text {water })}\right) \times 100 \\
\text { Hemolysis inhibition }(\%)=\left(\left(\mathrm{A}_{(\text {control })}-\mathrm{A}_{(\text {sample })}\right) / \mathrm{A}_{(\text {control })}\right) \times 100
\end{gathered}
$$

\subsubsection{Anti-diabetic Activity}

Anti-hyperglycemic activity of S-PSPC and a hydrolyzed fraction (S-PSPC h $_{\mathrm{h}}$ was investigated by evaluating the inhibition of both $\alpha$-amylase and $\alpha$-glucosidase activities. Inhibition of $\alpha$-amylase activity was estimated using the methods of Kumar et al. and Kajaria et al. which were slightly modified [23,24]. Briefly, $180 \mu \mathrm{L}$ of S-PSPC, acarbose (positive control) or ultrapure water (negative control) were introduced in dry tubes. Ninety $\mu \mathrm{L}$ of $\alpha$-amylase solution (5 IU /L) was added to each tube. The reaction mixtures were preincubated for $15 \mathrm{~min}$ at $37^{\circ} \mathrm{C}$. Then, $500 \mu \mathrm{L}$ of CNPG3 (2-chloro- $p$-nitrophenyl$\alpha$-D-maltotrioside) solution $(0.5 \mathrm{mg} / \mathrm{mL})$ were added under gentle stirring, followed by incubation for $10 \mathrm{~min}$ at $37^{\circ} \mathrm{C}$. The absorbances were measured at $\lambda=405 \mathrm{~nm}$. Inhibition 
of $\alpha$-glucosidase activity was estimated using the methods of Christudas et al., Bisht et al. and Qian et al., which were also slightly modified $[25,26]$. Briefly, $500 \mu \mathrm{L}$ in dry tubes of $\alpha$-glucosidase solution (2 UI/L) was introduced with $100 \mu \mathrm{L}$ of each dilution of S-PSPC or S-PSPC ${ }_{h}$, acarbose (positive control) or ultrapure water (negative control). S-PSPC $\mathrm{h}_{\mathrm{h}}$ was a hydrolyzed version of S-PSPC $\left(\mathrm{H}_{2} \mathrm{SO}_{4}, 50{ }^{\circ} \mathrm{C}, 30 \mathrm{~min}\right.$ ) for preliminary investigations of molar mass effects (data not shown). The mixture was pre-incubated for $15 \mathrm{~min}$ at $37^{\circ} \mathrm{C}$. Then, $100 \mu \mathrm{L}$ of $p$-NPG ( $p$-nitrophenyl- $\alpha$-D-glucopyranoside) solution $(4 \mathrm{mM})$ were added. The tubes were shaken and incubated for $20 \mathrm{~min}$ at $37^{\circ} \mathrm{C}$. One $\mathrm{mL}$ of $\mathrm{Na}_{2} \mathrm{CO}_{3}(0.2 \mathrm{M})$ was added to stop the reaction, and the absorbances were measured at $\lambda=405 \mathrm{~nm}$. Inhibition activity results were expressed regarding Equation (4) [27]. All the experiments were done in triplicate.

$$
\text { Inhibition }(\%)=\left(\left(\mathrm{A}_{(\text {control })}-\mathrm{A}_{(\text {sample })}\right) / \mathrm{A}_{(\text {control })}\right) \times 100
$$

\subsection{Statistical Analysis}

All statistical analyses were run using the statistical software SigmaPlot 12.5 (Systat Software). Data were expressed as mean \pm standard deviation (SD) of three replicate and evaluate by one-way analysis of variance (ANOVA). Post hoc procedures (Tukey test) were performed to analyze pairwise differences as well as Holm-Sidak method for multiple comparisons versus control group. Differences were considered significant for $p<0.05$.

\section{Results and Discussions}

\subsection{Structural Characterization of L-PSPC and S-PSPC}

\subsubsection{Main Biochemical Compositions}

The extraction yields of both L-PSPC (leaves) and S-PSPC (seeds) fractions are detailed in Figure 1, i.e., $46 \mathrm{~g} / \mathrm{kg}(4.60 \% \mathrm{w} / \mathrm{w})$ and $186 \mathrm{~g} / \mathrm{kg}(18.6 \% \mathrm{w} / \mathrm{w})$, respectively. Regarding the procedure of extractions, these values are consistent with the literature. Mass yields of water-soluble polysaccharides extracted from various parts of Plantago species are ranged from 1 to 20\%, as reported for Plantago major [6], Plantago asiatica [28] or Plantago notata [29]. Obviously, extraction yields are strongly influenced by the methodology, physicochemical parameters (temperature, $\mathrm{pH}$, reaction time, solid/liquid ratio, stirring, etc.), solvents, type and concentration of polysaccharides [30]. The higher yields are given for polysaccharides extracted from Plantago seeds (Psyllium) [31].

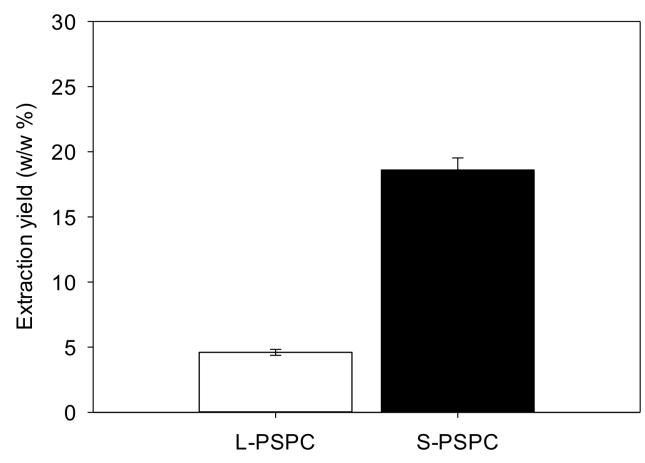

Figure 1. Extraction yields (w/w\%) of L-PSPC (leaves) and S-PCPC (seeds).

L-PSPC and S-PSPC are mainly composed of carbohydrates $(66.6 \%$ and $86.5 \% w / w$, respectively) (Table 1). Water-soluble polysaccharides extracted from Plantago ciliata leaves contained more uronic acids $(24.0 \% w / w)$ than those extracted from seeds $(7.96 \% w / w)$. Note that L-PSPC and S-PSPC are clearly enriched-polysaccharide fractions since both are poorly contaminated by proteins $(2.30 \%$ and $0.35 \% w / w)$ and phenol compounds (close to $0 \% w / w$ ). Three polysaccharide fractions from Plantago asiatica seeds (PLP-1, -2, -3) with high levels of total carbohydrates varying between $79.2 \%$ and $87 \%(w / w)$, and very low protein contents (around 1\% w/w) [32]. PSPN, a heteroxylan extracted from Plantago notata seeds, was composed of $85.6 \%$ of carbohydrates including $78 \%$ of neutral sugars [29]. 
Craeyveld et al. also described few amounts of uronic acids $(<5 \% w / w)$ in a seed husk arabinoxylan extracted from Plantago ovata Forsk [33]. A branched rhamnogalacturonan with side chains of arabinogalactan, was extracted in similar conditions from Plantago major leaves and mainly contained uronic acids $(59.3 \% \mathrm{w} / \mathrm{w})$ followed by neutral sugars $(39.1 \% w / w)$ [34]. Homogeneous acidic protein-bound heteropolysaccharides composed of carbohydrates $(89-92 \% w / w)$, proteins $(3-7 \% w / w)$ and uronic acids $(10-20 \% w / w)$ were extracted from seeds of Plantago depressa [35]. Thus, pectic substances and mainly heteroxylan are usually identified, respectively, from Plantago leaves or seeds by using water extraction bioprocesses [6,36].

Table 1. Biochemical composition of L-PSPC (leaves) and S-PCPC (seeds).

\begin{tabular}{|c|c|c|c|c|c|c|}
\hline \multirow{2}{*}{ Fractions } & \multicolumn{3}{|c|}{ Carbohydrate $(w / w \%)$} & \multirow{2}{*}{$\begin{array}{l}\text { Proteins } \\
(w / w \%)\end{array}$} & \multirow{2}{*}{$\begin{array}{l}\text { Phenols } \\
(w / w \%)\end{array}$} & \multirow{2}{*}{$\begin{array}{c}\text { Ash } \\
(w / w \%)\end{array}$} \\
\hline & Total & Neutral & Uronic Acids & & & \\
\hline L-PSPC & $66.6 \pm 1.42$ & $42.6 \pm 1.37$ & $24.0 \pm 1.12$ & $2.30 \pm 0.09$ & $0.6 \pm 0.03$ & $3.65 \pm 0.08$ \\
\hline S-PSPC & $86.5 \pm 4.32$ & $63.3 \pm 3.17$ & $7.96 \pm 0.39$ & $0.35 \pm 0.02$ & 0 & $5.12 \pm 0.24$ \\
\hline
\end{tabular}

\subsubsection{FTIR Spectroscopy}

FTIR spectra of both (a) L-PSPC and (b) S-PSPC are shown in Figure 2. The peaks at $3300-3400 \mathrm{~cm}^{-1}$ were attributed to O-H stretching vibration of both water and carbohydrates [29]. Aliphatic bending groups (C-H) were also observed close to $2900 \mathrm{~cm}^{-1}$ [37]. The characteristic absorption peaks around $1620 \mathrm{~cm}^{-1}$ were attributed to the vibration of carboxylate groups whereas the ones close to $1416 \mathrm{~cm}^{-1}$ could correspond to ester carbonyl groups of the carboxylic function of uronic acids [34]. The main peaks $\left(1034-1100 \mathrm{~cm}^{-1}\right)$ were attributed to $\mathrm{C}-\mathrm{O}$ functions of carbohydrates [38]. Assuming these observations, the results were in accordance with the biochemical compositions (see Section 3.1.1.). LPSPC could be a pectin-like fraction whereas S-PSPC could correspond to a heteroglycan containing few amounts of uronic acids (pectic contamination).

(a)

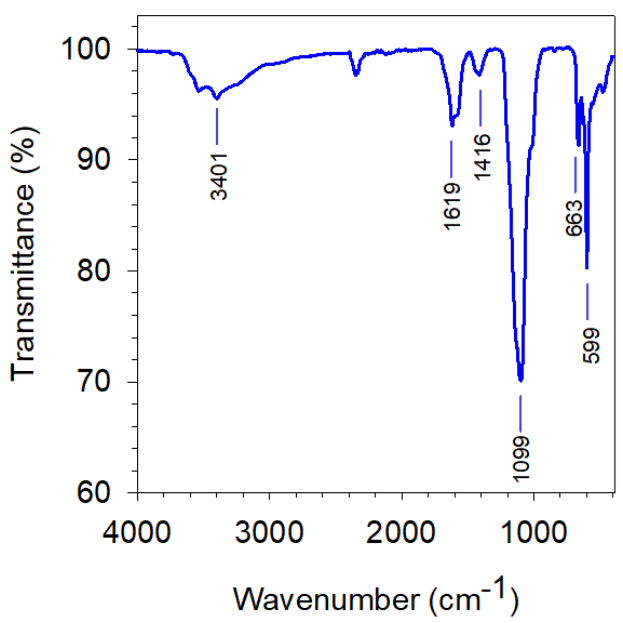

(b)

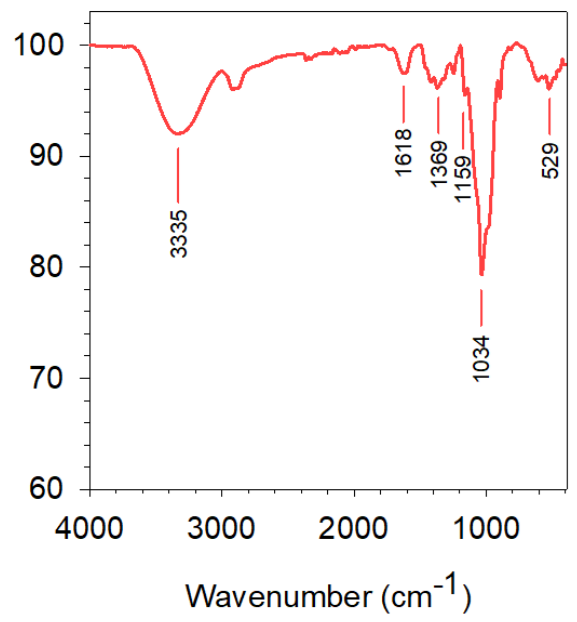

Figure 2. FTIR footprints of (a) L-PSPC (leaves) and (b) S-PCPC (seeds).

\subsubsection{Monosaccharide Compositions and Main Structural Features}

Results from HPAEC-PAD and GC/MS-EI experiments are given in Figure 3 for both (a) L-PSPC and (b) S-PSPC enriched-polysaccharide fractions. Data complementarity between the two methodologies was confirmed since no significant differences were observed among the data sets for L-PSPC $(p=0.805)$ and S-PSPC $(p=0.957)$. 
(a)

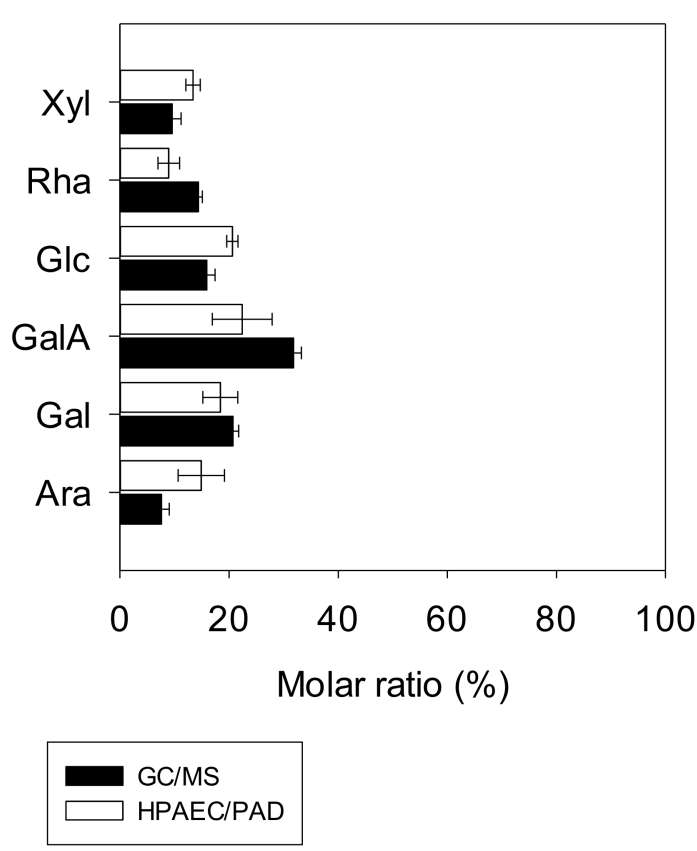

(b)

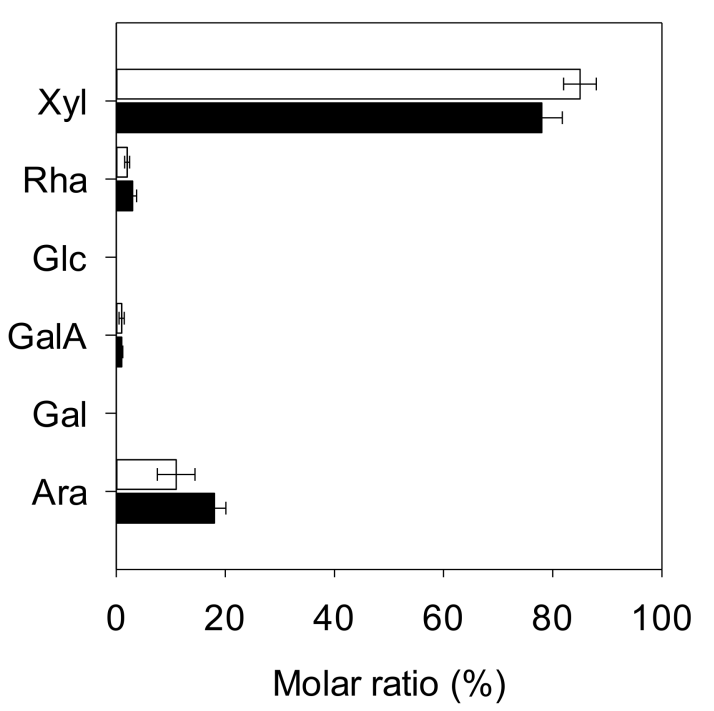

Figure 3. Monosaccharide compositions of (a) L-PSPC (leaves) and (b) S-PCPC (seeds). White and black bars, respectively correspond to the results obtained from HPAEC-PAD or GC/MS-EI experiments.

\section{- Composition of L-PCPC}

L-PSPC is composed of six main monosaccharides, highlighting its complexity, i.e., GalA (22.4-31.8\%), Gal (18.4-20.7\%), Glc (20.6-15.9\%), Rha (8.93-14.4\%), Xyl (13.4-9.58\%) and Ara (14.9-7.6\%). Accordingly, the composition is similar to some kinds of pectin.

Significant differences of monosaccharide compositions were described in the literature, depending on the extraction/purification methodologies, analytical procedures but also species of Plantaginaceae and obviously plant parts. Polysaccharides from Plantago major leaves, are often composed of GalA, Gal, Ara and Rha in addition to small amounts of Glc and Xyl [34,39]. Samuelsen et al. showed that water-soluble polysaccharides extracted from Plantago major leaves contained two subfractions (PMIa and PMIb). The first one was composed of Ara (38\%), Gal (49\%), Rha (6\%) and GalA (7\%) whereas the second one consisted of Ara (31\%), Gal (32\%), Xyl (18\%), Glc (7\%), Rha (5\%) and GalA (8\%) [6]. A water soluble heteroxylan extracted from Plantago notata leaves was composed of Gal (44\%), Rha (20\%), Glc (11\%), Ara (10\%) and GalA (13\%) [40]. Neutral rhamnoarabinogalactan were also extracted from Plantago lanceolata, which were rich in Gal (54\%), Ara (35\%) and Rha (11\%) [10]. Other water-soluble polysaccharides extracted from Plantago palmata leaves were composed of Gal (39\%), Ara/ Xyl (27\%), Man (Mannose) (5\%), Rha (10\%), Glc (5\%) and GalA (14\%) [9]. As stated before, these differences may be related to species, cultivation regions, extraction procedures, analysis methods, and samplings [41].

\section{- Composition of S-PCPC}

S-PSPC is easily identified as an arabinoxylan mainly composed of $\mathrm{Xyl}(85-78 \% \pm 3-$ 3.75), Ara (11-18\% $\pm 3.45-2.1)$, Rha $(2-3 \% \pm 0.45-0.75)$ and GalA $(1-1 \% \pm 0.47-0.21)$. With a Xyl:Ara molar ratio close to 4:1, results are in accordance with the literature concerning the identification of arabinoxylan or heteroxylan from Plantago seeds. Polysaccharide fractions (PLP-2 and PLP-3) isolated from Plantago asiatica were defined as arabinoxylan containing, respectively Xyl (61 and 56\%) and Ara (32.2 and 39.6\%) residues [32]. An arabinoxylan extracted from the pericarp of Plantago ovata Forssk. seeds was mainly composed of $\mathrm{Xyl}$ $(75 \%)$ and Ara (23\%) with a Xyl: Ara molar ratio close to 3: $1[42,43]$. Seeds from other Plantago species could contain heteroxylan as reported for an acidic one from Plantago 
major L., composed of Xyl (40\%), Ara (13\%), Glc (10\%), Gal (3\%), Rha (2\%), GalA (17\%) and GlcA (16\%) [44]. Benaoun et al. identified a neutral heteroxylan Plantago notata Lagasca seeds. This polysaccharide was mainly composed of Xyl (77\%), Rha (9\%), Ara (8\%), Gal (3\%), Glc (1\%) and GalA (2\%) [29]. Note that further structural characterization has been published for S-PSPC [45].

\subsection{Potential Health Benefits of L-PSPC and S-PSPC}

Few biological activities were analyzed (anticomplement, anti-inflammatory, antidiabetic) according to the structure/function relationship and data described in the literature. Thus, antidiabetic and anti-inflammatory activities were investigated on polysaccharides from Plantago seeds (S-PSPC) since psyllium-like polysaccharides are described for this biological potential. Besides, polysaccharides from Plantago leaves seem possessing specific anti-complement and phagocytotic properties, justifying the focus on L-PSPC. These choices are also in accordance with the uses of Plantago ciliata formulations by Nganga and traditional Algerian healers. Remedies from Plantago ciliata seeds are often used for constipation, stomach/guts pains and inflammatory problems (infusion) whereas those from leaves are more used for treating wounds (bandage), muscular pain and fever (decoction).

\subsubsection{Biological Activities of L-PSPC}

One of the important notable features of polymorphonuclear leukocytes activation would be an increase in phagocytic activity. To further investigate whether L-PSPC stimulate immune system, phagocytic activity of PMNs from human peripheral blood was monitored. Phagocytic activity of PMNs cells was examined by the uptake of opsonized C. albicans (see Section 2.6.1.). As shown in Figure 4a, significant enhancements of phagocytic activity were observed in PMNs treated with zymosan as positive control $(p<0.01)$ and L-PSPC $(p<0.01)$ comparing to negative controls (mean $26.7 \% \pm 2.08$ ).

(a)

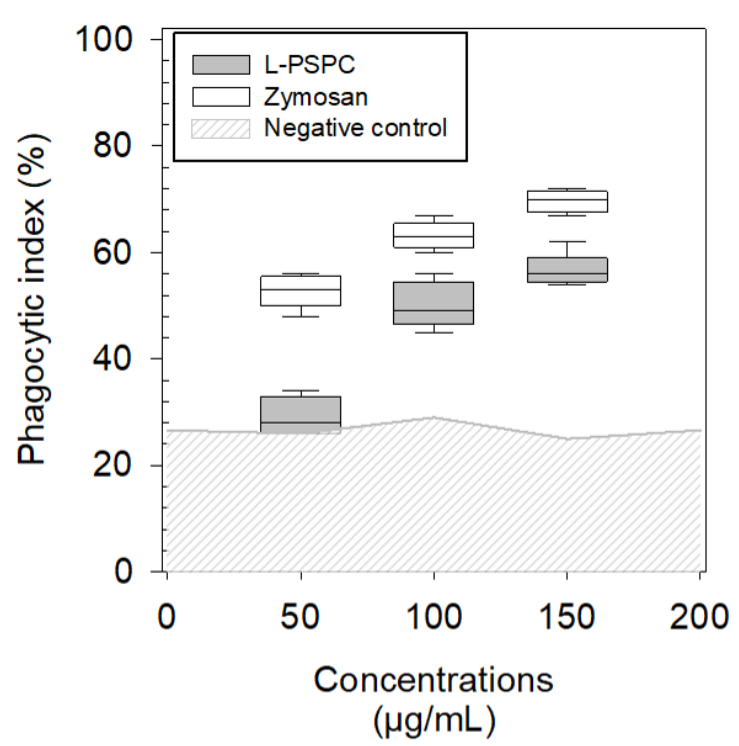

(b)

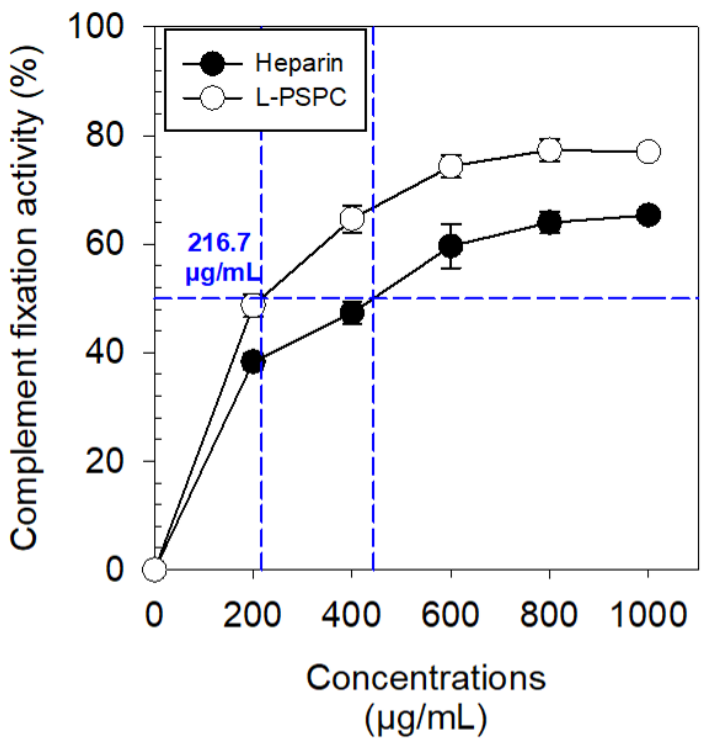

Figure 4. Biological effects of L-PSPC on (a) phagocytosis activity of polymorphonuclear leukocytes by the uptake of opsonized C. albicans and (b) complement fixation.

The results also seemed showing a dose-dependent increase in phagocytic activity in PMNs treated with doses ranging from 50 to $150 \mu \mathrm{g} / \mathrm{mL}$ of zymosan or L-PSPC $(p=0.644)$. Note that zymosan still showed the highest stimulated activity with an $\mathrm{IC}_{50}$ of $47.35 \mu \mathrm{g} / \mathrm{mL}$ against $99.75 \mu \mathrm{g} / \mathrm{mL}$ for L-PSPC. 
Figure $4 \mathrm{~b}$ showed that L-PSPC had a significant in vitro human complement fixing activity. $\mathrm{IC}_{50}$ for sodium heparin was around $443 \mu \mathrm{g} / \mathrm{mL}$, as reported for other works with values ranging from 420 to $750 \mu \mathrm{g} / \mathrm{mL}$ for sodium heparin [46]. Pure heparin gave better results with $\mathrm{IC}_{50}$ values between 16 to $36 \mu \mathrm{g} / \mathrm{mL}$ [47] and up to $150 \mu \mathrm{g} / \mathrm{mL}$ [48]. $\mathrm{IC}_{50}$ for L-PSPC was $216.7 \mu \mathrm{g} / \mathrm{mL}$ which was lower than for other pectic-like polysaccharides extracted from Plantago species. Samuelsen et al. reported $\mathrm{IC}_{50}$ between 35 and $60 \mu \mathrm{g} / \mathrm{mL}$ [6]. Accordingly, pectin usually show decent to strong anti-complement activities below $100 \mu \mathrm{g} / \mathrm{mL}$ due to their anionic character [10]. Heteroxylan from Plantago seeds (major and asiatica), consisting of a 1,3- and 1,4-linked $\beta$-D-Xyl $p$ backbone with short side chains, also showed potent complement activity, as reported with values ranging from 200 to $350 \mu \mathrm{g} / \mathrm{mL}$ [44].

Further experiments could also be done on S-PSPC to check this behavior. It is noteworthy that polysaccharide fractions with $\mathrm{IC}_{50}$ values higher than $200-400 \mu \mathrm{g} / \mathrm{mL}$ (sodium heparin) have no chance to emerge as new anti-complement drugs on the market. These results explained the uses of Plantago ciliatia leaves as remedies for treating wounds and specific inflammation by traditional healers.

\subsubsection{Biological Activities of S-PSPC}

\section{- Anti-inflammation potential of S-PCPC}

Activation of neutrophils not only results in the activation of membrane NADPH oxidase (NOX2) and the generation of reactive oxygen species (ROS) but also phenomenon of degranulation. Cytoplasmic granules fuse with the membrane of the phagosome. Microbicidal proteins and enzymes, in particular myeloperoxidase (MPO) in the following oxidative explosion. Various autoimmune diseases and chronic inflammation are observed due to these mechanisms [49]. Focusing on new ways to modulate the metabolic activity of neutrophils is today observed in the literature, e.g., through the uses of synthetic steroidal compounds with unwanted side effects. Various natural metabolites such as polyand oligosaccharides [50], flavonoids, tannins, alkaloids, coumarins but also essential oils could be proposed as an alternative [51]. In vitro anti-inflammatory effects of S-PCPC for inhibiting MPO and NADPH oxidase activities were analyzed as presented in Figure $5 \mathrm{a}, \mathrm{b}$. Both positive controls (dichlofenac and indomethacin) showed better $\mathrm{IC}_{50}$ values ( 2.71 and $3.77 \mu \mathrm{g} / \mathrm{mL}$ ) than S-PSPC (203 and $111 \mu \mathrm{g} / \mathrm{mL})$, respectively $(p<0.05)$. Inhibition of NOX2 by polysaccharides extracted from medicinal plants has shown varying potentials. The involved polysaccharide extracted from Artemisia tripartita leaves was mainly composed of Xyl, Ara, Glc, Gal, and GalN (Galactosamine) residues [52]. A water-soluble polysaccharide extracted from Bletilla striata (BSPb), a medicinal plant used by Chinese ancestors to treat burns in diabetics, exhibited an inhibitory effect on NOX2. It was of $260 \mathrm{kDa}$ and mainly composed of $\alpha$-D-(1,2)-Man $p$ and $\beta$-D-(1,4)-Glc $p$, with a molar ratio of 3:1 [53]. In the presence of Angiotensin II (Ang II), significant expression of NADPH oxidase was noted (73.6\%). Pretreating the cells with $5 \mu \mathrm{g} / \mathrm{mL}$ of BSPb resulted in an intense reduction in the expression of NOX2 and consequently the reduction in ROS, up to $30.2 \%$. This result was in the range of the reduction observed for PSPC at $5 \mu \mathrm{g} / \mathrm{mL}(23.4 \%)$. A water-soluble polysaccharide (PLPC) from Plantago asiatica L. seeds showed an anti-inflammatory effect on experimental colitis caused by dextran sulfate sodium salt (DSS) in BALB / c type rats [54]. 
(a)

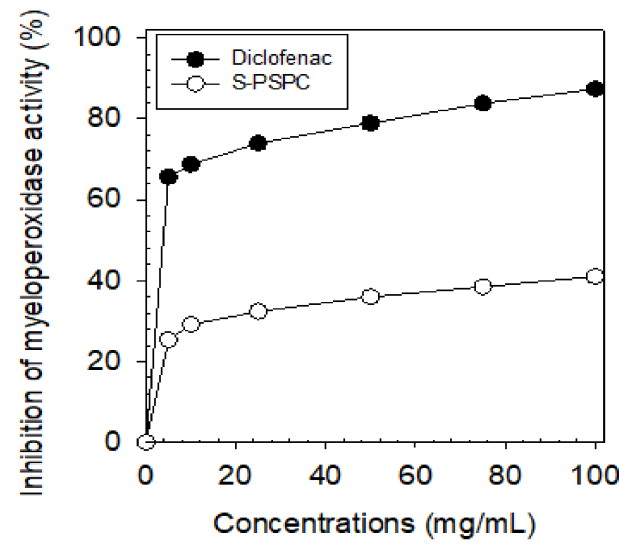

(c)

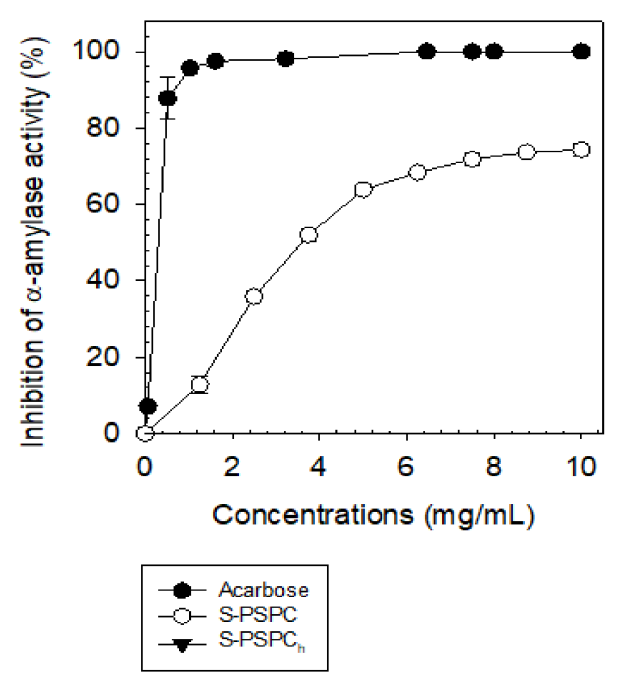

(b)

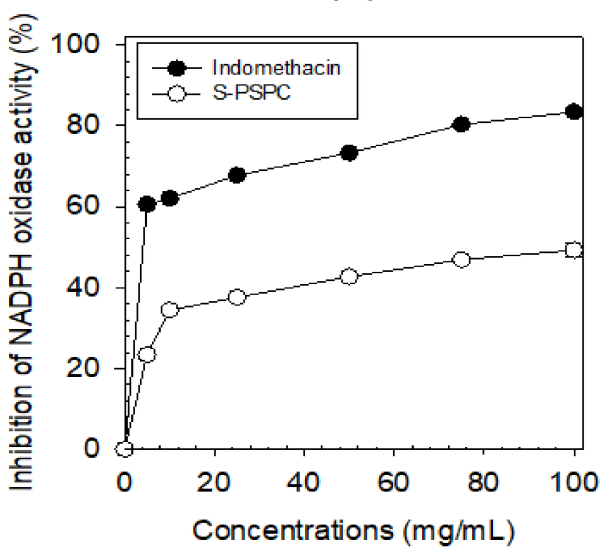

(d)

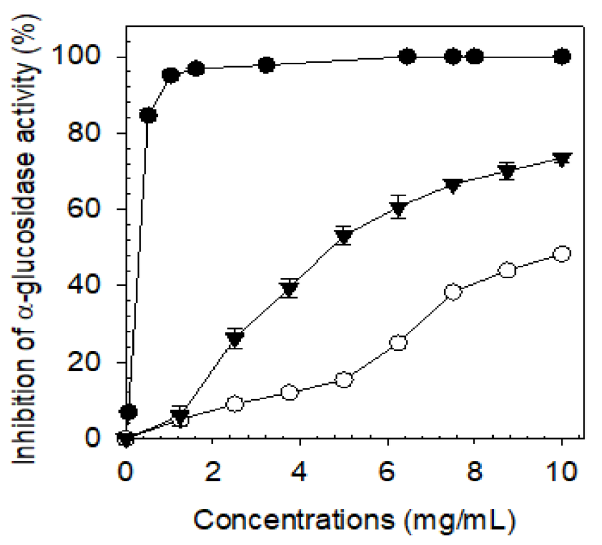

Figure 5. In vitro anti-inflammatory and anti-hyperglycemic effects of S-PSPC regarding inhibitions of (a) myeloperoxidase, (b) NADPH oxidase, (c) $\alpha$-amylase and (d) $\alpha$-glucosidase activities. S-PSPC is a hydrolyzed version of S-PSPC $\left(\mathrm{H}_{2} \mathrm{SO}_{4}, 50{ }^{\circ} \mathrm{C}, 30 \mathrm{~min}\right)$ for preliminary investigations of molar mass effects (data not shown).

In this study, PLPC was a heteroxylan of $3870 \mathrm{kDa}$. Histological observations highlighted a significant reduction in the length of colitis in the group treated with DSS compared to the control group, i.e., $64.3 \pm 4.1 \mathrm{~mm}$ and $85.6 \pm 4.5 \mathrm{~mm}$, respectively. Type 2 diabetes is a progressive disease that benefits from a complex therapeutic arsenal. Synthetic drugs prescribed for diabetics are increasingly numerous and more and more effective, e.g., hypoglycemic sulfonamides, acarbose, metformin, etc. These products can cause undesirable effects on human health such as the risk of hypoglycemia, weight gain or digestive disorders $[55,56]$.

- Antihyperglymic potential of S-PCPC

Today, alternative approaches are currently being targeted as the use of plant mucilages and/or gums with antihyperglycemic potential [57]. One of the regulatory pathways is to inhibit the functioning of $\alpha$-amylase and $\alpha$-glucosidase, thus preventing the cleavage of carbohydrates into oligosaccharides and their conversion to simple monosaccharides. Thus, it delays digestion process and prolongs their stay in the jejunum [58]. In vitro antihyperglycemic effects of S-PSPC using acarbose as positive control are reported in Figure 5 c, d. Acarbose showed better IC $\mathrm{I}_{50}$ values $(0.30$ and $0.32 \mathrm{mg} / \mathrm{mL})$ against $\alpha$-amylase and $\alpha$ glucosidase than S-PSPC ( 3.60 and $10 \mathrm{mg} / \mathrm{mL})$, respectively $(p<0.05)$. The results observed 
for the positive control were consistent with the literature with values ranging from 0.05 to $0.60 \mathrm{mg} / \mathrm{mL}$ [59]. As reported by Chen et al., inhibition of $\alpha$-glucosidase activity was inversely proportional to molar mass and $\mathrm{S}_{-\mathrm{PSPC}} \mathrm{C}_{\mathrm{h}}$ showed an $\mathrm{IC}_{50}$ of $4.71 \mathrm{mg} / \mathrm{mL}$ [60]. Note that S-PSPC had a molar mass of $700 \mathrm{kDa}$ [45]. A heteroxylan extracted from Plantago notata seeds also showed a moderate inhibitory potential at $10 \mathrm{mg} / \mathrm{mL}$ (58\%) [29]. Variations in monosaccharide compositions are also classically involved in these differences [61]. Inhibitory capacity of heteroxylan and arabinoxylan are due to Xyl:Ara ratio and degree of substitution, highly substituted ones presenting the best $\mathrm{IC}_{50}$ values. Arabinoxylan also uncompetitively inhibit $\alpha$-glucosidase [62]. Treating diabetic rats with an arabinoxylan (PLP) isolated from Plantago asiatica seeds leaded to a reduction in blood glucose levels [63]. PLP significantly inhibited $\alpha$-amylase activity and diffusion of glucose, in vitro. At 2.5 $\mathrm{mg} / \mathrm{mL}$, PLP reduced $\alpha$-amylase activity by $10 \%$ compared to the negative control, which was lower than for S-PSPC at the same concentration (36\%). Inhibition of $\alpha$-amylase could be due to the number of free carboxylic groups [64]. Note that S-PSPC contained few uronic acids $(8 \% w / w)$. Adsorption of polysaccharides to starch remains the most reported hypothesis, which would prevent the hydrolytic activity of enzymes such as $\alpha$-amylase [65]. Consuming Plantago ovata fibers (rich in arabinoxylan) improved postprandial glycemic index and insulin sensitivity in rats $[43,66]$. Dietary fibers from Plantago ovata may also reduce blood glucose levels in patients with type II diabetes [67]. Bisht et al. tested in vitro antihyperglycemic potency of Acacia tortilis polysaccharide (AG), showing its potential as an effective remedy for treating diabetes mellitus. $\mathrm{IC}_{50}$ of $\mathrm{AG}$ was around $0.7 \mathrm{mg} / \mathrm{mL}$ for $\alpha-$ glucosidases extracted from rats and $0.5 \mathrm{mg} / \mathrm{mL}$ for those extracted from yeast [25]. More recently, an arabinan-rich polysaccharide exhibited significant $\alpha$-glucosidase inhibitory activities $[60,68]$. These observations are consistent with traditional uses of Plantago ciliata seeds in medicine for reducing blood sugar levels [11].

Finally, all these preliminary results assessed the biological potential of both L-PSPC (pectin-like) and S-PSPC (arabinoxylan-like), giving an understanding as to why Plantago ciliata leaves and seeds are widely used in Algerian ethnobotany approach to treat diabetes and diseases often associated with inflammation. Further experiments should be needed in the future, as instance, the analysis of the antiproliferative and in vitro digestion activities of both fractions to better comprehend their biological potentials in Nutraceutics and Inflammation processes. In vivo (cells, animals and clinical) experiments should complete these results to assess their uses as new healthy drugs (or based-drug compounds).

Author Contributions: Conceptualization, G.P., N.A., Z.B.; methodology, C.D., G.P., N.A., P.D.; validation, C.D., G.P., N.A., P.D.; formal analysis, C.G., F.B., G.P., N.A., S.A., T.C., Z.B.; investigation, C.D., F.B., N.A., P.D., S.A., T.C., Z.B.; writing—original draft preparation, G.P., N.A., Z.B.; writingreview and editing, G.P., Z.B.; supervision, G.P., M.D.O.E.H., P.M., Z.B.; project administration, M.D.O.E.H., P.M.; funding acquisition, M.D.O.E.H., P.M. All authors have read and agreed to the published version of the manuscript.

Funding: This work has been sponsored by Campus France and the Hubert Curien Tassili programPhase II (15MDU933).

Institutional Review Board Statement: The study was conducted according to the guidelines of the Declaration of Helsinki, and approved by Ethics Research Committee of Laboratoire de Biologie Médicales IBN ROCHD (Ghardaïa, Algeria), number 1154/He/Ce/Z/11/LSPSPC, 23 August 2017.

Conflicts of Interest: The authors declare no conflict of interest.

\section{References}

1. Sung, B.; Prasad, S.; Gupta, S.C.; Patchva, S.; Aggarwal, B.B. Regulation of Inflammation-Mediated Chronic Diseases by Botanicals. Adv. Bot. Res. 2012, 62, 58-94.

2. Yang, X.; Guo, D.; Zhang, J.; Wu, M. Characterization and anti-tumor activity of pollen polysaccharide. Int. Immunopharmacol. 2007, 7, 401-408. [CrossRef]

3. Ooi, V.E.C.; Liu, F. Immunomodulation and anti-cancer activity of polysaccharide-protein complexes. Curr. Med. Chem. 2000, 7, 715-729. [CrossRef] [PubMed] 
4. Shao, B.M.; Xu, W.; Dai, H.; Tu, P.; Li, Z.; Gao, X.M. A study on the immune receptors for polysaccharides from the roots of Astragalus membranaceus, a Chinese medicinal herb. Biochem. Biophys. Res. Commun. 2004, 320, 1103-1111. [CrossRef] [PubMed]

5. Huang, D.F.; Tang, Y.F.; Nie, S.P.; Wan, Y.; Xie, M.Y.; Xie, X.M. Effect of phenylethanoid glycosides and polysaccharides from the seed of Plantago asiatica L. on the maturation of murine bone marrow-derived dendritic cells. Eur. J. Pharmacol. 2009, 620, 105-111. [CrossRef] [PubMed]

6. Samuelsen, A.B.; Paulsen, B.S.; Weld, J.K.; Knutsen, S.H.; Yamada, H. Characterization of a biologically active arabinogalactan from the leaves of Plantago major L. Carbohydr. Polym. 1998, 35, 145-153. [CrossRef]

7. Hu, J.L.; Nie, S.P.; Li, C.; Xie, M.Y. In vitro fermentation of polysaccharide from the seeds of Plantago asiatica L. by human fecal microbiota. Food Hydrocoll. 2013, 33, 384-392. [CrossRef]

8. Galisteo, M.; Sanchez, M.; Vera, R.; Gonzalez, M.; Anguera, A.; Duarte, J.; Zarzuelo, A. A diet supplemented with husks of Plantago ovata deduces the development of endothelial dysfunction, hypertension, and obesity by affecting adiponectin and TNF- $\alpha$ in obese zucker rats. J. Nutr. 2005, 135, 2399-2404. [CrossRef]

9. Biringanine, G.; Vray, B.; Vercruysse, V.; Vanhaelen-Fastre, R.; Vanhaelena, M.; Duez, P. Polysaccharides extracted from the leaves of Plantago palmata Hook.f. induce nitric oxide and tumor necrosis factor- $\alpha$ production by interferon- $\gamma$-activated macrophages. Nitric Oxide 2005, 12, 1-8. [CrossRef]

10. Kardosova, A.; Machova, E. Antioxidant activity of medicinal plant polysaccharides. Fitoterapia 2006, 77, 367-373. [CrossRef]

11. Djeridane, A. Evaluation du pouvoir antioxydant et de l'inhibition d'enzymes (la Carboxylestérase et l'Acylase) par des extraits phénoliques de dix-neuf plantes médicinales locales. Thèse de Doctorat, Ecole Normale Supérieure De Kouba-Alger, Kouba-Alger, Algeria, 2008.

12. Dubois, M.; Gilles, K.A.; Hamilton, J.K.; Pebers, P.A.; Smith, F. Colorimetric method for determination of sugar and relayed substances. Anal. Chem. 1956, 28, 350-356. [CrossRef]

13. Monsigny, M.; Petit, C.; Roche, A.C. Colorimetric determination of neutral sugars by a resorcinol sulfuric acids micromethod. Anal. Biochem. 1988, 175, 525-530. [CrossRef]

14. Blumenkrantz, N.; Asboe-Hansen, G. New method for quantitative determination of uronic acids. Anal. Biochem. 1973, 54, 484-489. [CrossRef]

15. Bradford, M.M. A rapid and sensitive method for the quantitation of microgram quantities of protein utilizing the principle of protein-dye binding. Anal. Biochem. 1976, 72, 248-254. [CrossRef]

16. Singleton, V.L.; Rossi, J.A. Colorimetry of total phenolics with phosphomolybdic-phosphotungstic acid reagents. Am. J. Enol. Vitic. 1965, 16, 144-158.

17. Pierre, G.; Graber, M.; Rafiliposon, B.A.; Dupuy, C.; Orvain, F.; De Crignis, M.; Maugard, T. Biochemical composition and changes of extracellular polysaccharides (ECPS) produced during microphytobenthic biofilm development (Marennes-Oléron, France). Microb. Ecol. 2011, 63, 157-169. [CrossRef] [PubMed]

18. Ghoneum, M.; Gollapudi, S. Phagocytosis of Candida albicans by metastatic and non-metastatic human breast cancer cell lines in vitro. Cancer Detect. Prev. 2004, 28, 17-26. [CrossRef]

19. Tavanti, A.; Campa, D.; Bertozzi, A.; Pardini, G.; Naglik, J.R.; Barale, R.; Senesi, S. Candida albicans isolates with different genomic backgrounds display a differential response to macrophage infection. Microb. Infect. 2006, 8, 791-800. [CrossRef]

20. Wanikiat, P.; Panthong, A.; Sujayanon, P.; Yoosook, C.; Rossi, A.G.; Reutrakul, V. The anti-inflammatory effects and the inhibition of neutrophil responsiveness by Barleria lupulina and Clinacanthus nutans extracts. J. Ethnopharmacol. 2008, 116, 234-244. [CrossRef]

21. Meziti, A. Régulation de L'inflammation par les Extraits de Rubus fruticosus et Zizyphus vulgaris. Ph.D. Thesis, Université Ferhat Abbas-Sétif, Sétif, Algeria, 2018.

22. Boudoukha, C. Etude de Certaines Fonctions du Neutrophile Humain et Leur Modulation par les Extraits de Santolina chamaecyparissus. Ph.D. Thesis, Université Ferhat Abbas-Sétif, Sétif, Algeria, 2018.

23. Kumar, A.; Lakshman, K.; Jayaveera, K.; Shekar, S.; Swamy, N.; Khan, S.; Velumurga, C. In vitro $\alpha$-amylase inhibition and antioxidant activities of methanolic extract of Amaranthus caudatus Linn. Oman Med. J. 2011, 26, 166-170. [CrossRef] [PubMed]

24. Kajaria, D.; Tripathi, J.; Tripathi, Y.B.; Tiwari, S. In-vitro $\alpha$-amylase and glycosidase inhibitory effect of ethanolic extract of antiasthmatic drug-Shirishadi. J. Adv. Pharm. Technol. Res. 2013, 4, 206-209. [CrossRef] [PubMed]

25. Bisht, S.; Kant, R.; Kumar, V. $\alpha$-D-glucosidase inhibitory activity of polysaccharide isolated from Acacia tortilis gum exudate. Int. J. Biol. Macromol. 2013, 59, 214-220. [CrossRef]

26. Qian, J.Y.; Bai, Y.Y.; Tang, J.; Chen, W. Antioxidation and $\alpha$-glucosidase inhibitory activities of barley polysaccharides modified with sulfation. LWT-Food Sci. Technol. 2015, 64, 104-111. [CrossRef]

27. Telagari, M.; Hulltti, K. In-vitro $\alpha$-amylase and $\alpha$-glucosidase inhibitory activity of Adiantum caudatum Linn. and Celosia argentea Linn. extracts and fractions. Ind. J. Pharmacol. 2015, 47, 425-429.

28. Gong, L.; Zhang, H.; Niu, Y.; Chen, L.; Liu, J.; Alaxi, S.; Shang, P.; Yu, W.; Yu, L. A novel alkali extractable polysaccharide from Plantago asiatica L. seeds and its radical-scavenging and bile acid-binding activities. J. Agric. Food Chem. 2015, 63, 569-577. [CrossRef] [PubMed]

29. Benaoun, F.; Delattre, C.; Boual, Z.; Ursu, A.V.; Vial, C.; Gardarin, C.; Wadouachi, A.; Le Cerf, D.; Varacavoudin, T.; Ould El-Hadj, M.D.; et al. Structural characterization and rheological behavior of a heteroxylan extracted from Plantago notata Lagasca (Plantaginaceae) seeds. Carbohydr. Polym. 2017, 175, 96-104. [CrossRef] 
30. Han, N.; Wang, L.; Song, Z.; Lin, J.; Ye, C.; Liu, Z.; Yin, J. Optimization and antioxidant activity of polysaccharides from Plantago depressa. Int. J. Biol. Macromol. 2016, 93, 644-654. [CrossRef]

31. Guo, Q.; Cui, S.W.; Wang, Q.; Young, J.C. Fractionation and physicochemical characterization of psyllium gum. Carbohydr. Polym. 2008, 73, 35-43. [CrossRef]

32. Yin, J.; Lin, H.; Li, J.; Wang, Y.; Cui, S.W.; Nie, S.; Xie, M. Structural characterization of a highly branched polysaccharide from the seeds of Plantago asiatica L. Carbohydr. Polym. 2012, 87, 2416-2424. [CrossRef]

33. Craeyveld, V.V.; Delcour, J.A.; Christophe, M.C. Extractability and chemical and enzymic degradation of psyllium (Plantago ovata Forsk) seed husk arabinoxylans. Food Chem. 2009, 112, 812-819. [CrossRef]

34. Lukova, P.; Nikolova, M.; Petit, E.; Elboutachfaiti, R.; Vasileva, T.; Katsarov, P.; Manev, H.; Gardarin, C.; Pierre, G.; Michaud, P.; et al. Prebiotic activity of poly- and oligosaccharides obtained from Plantago major L. leaves. Appl. Sci. 2020, 10, 2648. [CrossRef]

35. Zha, H.; Wang, Q.; Sun, Y.; Yang, B.; Wang, Z.; Chai, G.; Guan, Y.; Shu, Z.; Lei, X.; Kuang, H. Purification, characterization and immunomodulatory effects of Plantago depressa polysaccharides. Carbohydr. Polym. 2014, 112, 63-72. [CrossRef]

36. Olennikov, D.N.; Tankhaeva, L.M.; Samuelsen, A.B. Quantitative analysis of polysaccharides from Plantago major leaves using the dreywood method. Chem. Nat. Compd. 2006, 42, 265-268. [CrossRef]

37. Bichara, L.C.; Alvarez, P.E.; Bimbi, M.V.F.; Vaca, H.; Gervasi, C.; Brandán, S.A. Structural and spectroscopic study of a pectin isolated from citrus peel by using FTIR and FT-Raman spectra and DFT calculations. Infrared Phys. Technol. 2016, 76, 315-327. [CrossRef]

38. Patel, M.K.; Tanna, B.; Mishra, A.; Jha, B. Physicochemical characterization, antioxidant and anti-proliferative activities of a polysaccharide extracted from psyllium (P. ovata) leaves. Int. J. Biol. Macromol. 2018, 118, 976-987. [CrossRef]

39. Gorin, A.G. Polysaccharides from Plantago major leaves. I. Analysis of monosaccharide composition of polysaccharide complex. Chem. Abstracts 1966, 64, 8277.

40. Boual, Z.; Kemassi, A.; Daddi Bouhoun, M.; Michaud, P.; Ould El Hadj, M.D. Isolation and partial characterization of watersoluble polysaccharides from one saharian medicinal plant: Plantago Notata Lagasca. Int. Conf. Environ. Chem. Biol. 2012, 49, 61-65.

41. Zhong, X.K.; Jin, X.; Lai, F.Y.; Lin, Q.S.; Jiang, J.G. Chemical analysis and antioxidant activities in vitro of polysaccharide extracted from Opuntia ficus indica Mill. cultivated in China. Carbohydr. Polym. 2010, 82, 722-727. [CrossRef]

42. Fischer, M.H.; Yu, N.; Gray, G.R.; Ralph, J.; Anderson, L.; Marlett, J.A. The gel-forming polysaccharide of psyllium husk (Plantago ovata Forsk). Carbohydr. Res. 2004, 339, 2009-2017. [CrossRef] [PubMed]

43. Saghir, S.; Iqbal, M.S.; Hussain, M.A.; Koschella, A.; Heinze, T. Structure characterization and carboxymethylation of arabinoxylan isolated from Ispaghula (Plantago ovata) seed husk. Carbohydr. Polym. 2008, 74, 309-317. [CrossRef]

44. Samuelsen, A.B.; Ingrid, L.; Djahromi, J.M.; Paulsen, B.S.; Wold, J.K.; Knutsen, S.H. Structural features and anti-complementary activity of some heteroxylan polysaccharide fractions from the seeds of Plantago major L. Carbohydr. Polym. 1999, 38, 133-143. [CrossRef]

45. Addoun, N.; Boual, Z.; Delattre, C.; Ursu, A.V.; Desbrières, J.; Le Cerf, D.; Gardarin, C.; Hentati, F.; Ould El-Hadj, M.D.; Michaud, P.; et al. Structural features and rheological behavior of a water-soluble polysaccharide extracted from the seeds of Plantago ciliata Desf. Int. J. Biol. Macromol. 2020, 155, 1333-1341. [CrossRef]

46. Blondin, C.; Chaubet, F.; Nardella, A.; Sinquin, C.; Jozefonvicz, J. Relationships between chemical characterstics and anticomplementary activity of fucans. Biomaterials 1996, 17, 597-603. [CrossRef]

47. Xi, Z.; Chen, W.; Wu, Z.; Wang, Y.; Zeng, P.; Zhao, G.; Li, X.; Sun, L. Anti-complementary activity of flavonoids from Gnaphalium affine D. Don. Food Chem. 2012, 130, 165-170. [CrossRef]

48. Xie, G.; Schepetkin, I.A.; Quinn, M.T. Immunomodulatory activity of acidic polysaccharides isolated from Tanacetum vulgare L. Int. Immunopharmacol. 2007, 7, 1639-1650. [CrossRef]

49. Lojek, A.; Denev, P.; Ciz, M.; Vasicek, O.; Kratchanova, M. The effects of biologically active substances in medicinal plants on the metabolic activity of neutrophils. Phytochem. Rev. 2014, 13, 499-510. [CrossRef]

50. Song, X.; Shen, Q.; Liu, M.; Zhang, C.; Zhang, L.; Ren, Z.; Wang, W.; Dong, Y.; Wang, X.; Zhang, J.; et al. Antioxidant and hepatoprotective effects of intracellular mycelium polysaccharides from Pleurotus geesteranus against alcoholic liver diseases. Int. J. Biol. Macromol. 2018, 114, 979-988. [CrossRef]

51. Iwalewa, E.O.; McGaw, L.J.; Naidoo, V.; Eloff, J.N. Inflammation: The foundation of diseases and disorders. A review of phytomedicines of South African origin used to treat pain and inflammatory conditions. Afr. J. Biotechnol. 2007, 6, $2868-2885$.

52. Xie, G.; Schepetkin, I.A.; Siemsen, D.W.; Kirpotina, L.N.; Wiley, J.A.; Quinn, M.T. Fractionation and characterization of biologically active polysaccharides from Artemisia tripartita. Phytochem. 2008, 69, 1359-1371. [CrossRef]

53. Wang, Y.; Liu, D.; Chen, S.; Wang, Y.; Jiang, H.; Yin, H. A new glucomannan from Bletilla striata: Structural and anti-fibrosis effects. Fitoterapia 2014, 92, 72-78. [CrossRef] [PubMed]

54. Huang, D.; Xia, Q.; Li, F.; Yang, W.; Nie, S.; Xie, M. Attenuation of intestinal inflammation of polysaccharides from the seeds of Plantago asiatica L. as affected by ultrasonication. J. Food Biochem. 2018, 42, e12656-e12663. [CrossRef]

55. Stipp, M.C.; de Lacerda Bezerra, I.; Corso, C.R.; dos Reis Livero, F.A.; Lomba, L.A.; Caillot, A.R.C.; Zampronio, A.R.; QueirozTelles, J.E.; Klassen, G.; Ramos, E.A.S.; et al. Necroptosis mediates the antineoplastic effects of the soluble fraction of polysaccharide from red wine in Walker-256 tumor-bearing rats. Carbohydr. Polym. 2017, 160, 123-133. [CrossRef] 
56. Wasser, S. Medicinal mushrooms as a source of antitumor and immunomodulating polysaccharides. Appl. Microbiol. Biotechnol. 2003, 60, 258-274

57. Dey, L.; Attele, A.S.; Yuan, C.S. Alternative therapies for type 2 diabetes. Altern. Med. Rev. 2002, 7, 45-58.

58. Yu, L.; Xie, Z.; Liu, W. Nutraceutical and health properties of psyllium. In Cereals and Pulses: Nutraceutical Properties and Health Benefits, 1st ed.; Yu, L., Tsao, R., Shahidi, F., Eds.; Wiley Blackwell: Hoboken, NJ, USA, 2012; pp. 1-139.

59. Poovitha, S.; Parani, M. In vitro and in vivo $\alpha$-amylase and $\alpha$-glucosidase inhibiting activities of the protein extracts from two varieties of bitter gourd (Momordica charantia L.). BMC Compl. Alternative Med. 2016, 16, 185-200. [CrossRef] [PubMed]

60. Chen, C.; Zhang, B.; Huang, Q.; Fu, X.; Liu, R.H. Microwave-assisted extraction of polysaccharides from Moringa oleifera Lam. leaves: Characterization and hypoglycemic activity. Ind. Crop. Prod. 2017, 100,1-11. [CrossRef]

61. Jia, X.; Hu, J.; He, M.; Zhang, Q.; Li, P.; Wan, J.; He, C. $\alpha$-Glucosidase inhibitory activity and structural characterization of polysaccharide fraction from Rhynchosia minima root. J. Funct. Foods 2017, 28, 76-82. [CrossRef]

62. Malunga, L.N.; Izydorczyk, M.; Beta, T. Antiglycemic Effect of Water Extractable Arabinoxylan from wheat aleurone and bran. J. Nutr. Metab. 2017, 2017, 5784759. [CrossRef]

63. Nie, Q.; Hu, J.; Gao, H.; Fan, L.; Chen, H.; Nie, S. Polysaccharide from Plantago asiatica L. attenuates hyperglycemia, hyperlipidemia and affects colon microbiota in type 2 diabetic rats. Food Hydrocoll. 2019, 86, 34-42. [CrossRef]

64. Gourgue, C.M.P.; Champ, M.M.J.; Lozano, Y.; Delort-Laval, J. Dietary fiber from mango by products: Characterization and hypoglycemic effect determined by in vitro methods. J. Agric. Food Chem. 1992, 40, 1864-1868. [CrossRef]

65. Annison, G.; Topping, D.L. Nutritional role of resistant starch: Chemical structure vs Physiological function. Annu. Rev. Nutr. 1994, 14, 297-320. [CrossRef] [PubMed]

66. Madgulkar, A.R.; Rao, M.R.P.; Warrier, D. Characterization of Psyllium (Plantago ovata) polysaccharide and its uses. In Polysaccharides; Ramawat, K.G., Mérillon, J.M., Eds.; Springer International Publishing: Switzerland, 2014; pp. 871-890.

67. Hussain, M.A.; Muhammad, G.; Jantan, I.; Bukhari, S.N.A. Psyllium arabinoxylan: A versatile biomaterial for potential medicinal and pharmaceutical applications. Polym. Rev. 2015, 56, 1-30. [CrossRef]

68. Zhang, Z.; Kong, F.; Ni, H.; Mo, Z.; Wan, J.B.; Hua, D.; Yan, C. Structural characterization, $\alpha$-glucosidase inhibitory and DPPH• scavenging activities of polysaccharides from guava. Carbohydr. Polym. 2016, 144, 106-114. [CrossRef] [PubMed] 